\title{
XX.-Remarks on the Duty of the Steam Enyines employed in the Mines of Cornwall at different periods.
}

By JOHN S. ENYS, ESQ., Assoc. Inst. C.E.*

Read January 14, 1840.

THE advantage of an intimate union of theoretical and practical knowledge in the application of steam power will be readily admitted, and the certainty, that in case of difference of opinion the latter ought to be relied on, should lead us to a cautious investigation of the conditions which may influence the results: it will be the object of my remarks, which embrace only a portion of this subject, to further this union by an attempt to trace the progress of improvement in Cornwall, and to point out some of the principal causes by which it appears to have been effected; the inquiry may perhaps be found deserving of attention, since extravagant and undefined ideas have been prevalent in Cornwall of an almost unlimited increase of duty, while elsewhere the reported duty has been sometimes treated as incredible and inconsistent with the laws of Nature.

I would observe in the first place that no change has taken place in the use of the term duty, or in the principles of its calculation, since its introduction by Watt, yet it may have been materially influenced by causes unconnected with the engine, viz., by the reduction of pitwork friction, and the greater average depth of the shafts from which the water is drawn; the advantage due to the former cause is however in some degree counterbalanced by the improvement

- The author, in compliance with the regulations of the Institution of Civil Engineers, soon after his admission as an Associate forwarded Remarks on Cornish Engines to that Society, an abstract of which was read in January, 1840, and published in the Minutes of that Session. At this period it should be remembered that a duty of 70 millions had been discredited, and the usual proofs had been treated as inconclusive by many persons.

During the last two years, several publications and numerous discussions have rendered this subject more familiar to the public, and the author's opinions on several points have undergone some modification, so that when he was requested, in October, 1841, to revise the paper for publication, it seemed most advisable that notes in explanation should be added.

$$
\text { 0 } 002
$$


of the actual, in proportion to the calculated, delivery of water, arising from the better workmanship of the pitwork, and the greater attention paid to the state of its repair by the managers of the mines under whose care it is placed to the exclusion of the engineers, to whom the construction and care of the steam engines are entrusted.

In calculations necessary for the comparison of the power and work performed by steam, it will be convenient to estimate the force and space of action of the steam on the piston in terms similar to those which have been so long employed for duty, viz., of lbs. raised one foot high per bushel of coal, but care must be taken in reference to the older duty, to raise it to the present standard of the imperial bushel of $94 \mathrm{lbs}$. of Welsh coal; an addition of 5 per cent. to the duty of the Winchester bushel, is an approximation, I believe, in favour of the old engines.

In $1827 \mathrm{Mr}$. Davies Gilbert, in the Philosophical Transactions, and Mr. Tredgold, in his work on Steam Engines, published in the same year, brought forward independent investigations respecting the power to be derived from steam, and both parties adopted the unit of one cubic foot of water; the former, in reference to the Cornish idea of work performed, estimated the weight of water that would rise 34 feet into a perfect vacuum, assumed to have been formed by the condensation of steam of atmospheric pressure, produced from one cubic foot of water. Tredgold, on the contrary, on the engineer's view of power, calculated the power that could be exerted on a piston by the volume of steam of atmospheric strength formed from one cubic foot of water, obtained by multiplying together the pressure per square foot, and the space through which it could act. The results will be similar if the same volumes of steam are assumed-yet the method of Tredgold seems preferable, since it can be extended to the steam power that may be derived from steam of any pressure, as shown in the Report of the Cornwall Polytechnic Society for the year 1835.

Annexed is a corrected table of pressures translated from the French tables of Clement Desormes, in which the French estimate of the atmosphere is taken at $29 \cdot 92$ inches of mercury.

The obstacle to the general application of the correct Obstacles to the correct
application of Theory. method of expansion pressure calculations, appears to have been the attempt to use the pressure in the boiler instead of the pressure in the cylinder at the closing of the steam valve, as the basis of calculations of the gross power supplied at each stroke by the boilers, and of the gross 
power exerted on the piston, which differs from the former wherever expansion is used.

In engines not worked expansively, the boiler's supply is a measure of the steam power-but in expansive engines an addition must be made of the power derived from the steam after the communication between the cylinder and boiler has been closed.

A practice has been also adopted among engineers of deducting the resistances arising from the imperfect vacuum from the boiler pressure, and calling the remainder the gross power on the piston, and of occasionally calculating the expansion pressures at different parts of the stroke from this erroneous basis : this seems to have arisen from a reference to indicator diagrams of double acting engines, in which the difference of the pressure on the two sides of the piston is shown.

The errors due to the belief that the consumption of fuel was proportional to the temperature, which at one time led to the expectation of an enormous advantage from the use of high steam, may be considered as entirely exploded, and the necessity of the introduction of the wasted atmosphere in comparative estimates, where steam of different pressure is used, is also acknowledger. The atmosphere wasted in high pressure engines obviously bears a different ratio to the pressure as higher steam is employed, and the loss theoretically becomes less; in practice we can prevent escape of heat by perfect clothing of the boilers and engines.

I shall now endeavour to show that the Cornish engines are worked under such conditions that a large proportion of the advantage of the expansive action of the steam is rendered available on the piston; but previous to any remarks on this point, I am bound to advert to the corrections which are required in the application to Cornish engines of Boyle's and Marriotte's law, that the pressures of elastic fluids are inversely as the volumes, when the temperature is constant.

Correction of the deficiency

In the first place, the temperature is not constant, but of Water in high Steam.

decreases in an unknown ratio, as there is a deficiency of water in a given quantity of high steam to produce another quantity of lower steam of a density exactly proportional to the volumes of expansionyet for practical purposes the pressures may be assumed Correction tor Steam Jacket. proportional to the water at the end of each volume of expansion, unless the temperature is raised by the effect of the correction due to the steam jacket usually employed, containing steam of $270^{\circ}$ Fahrenheit, 
while the steam in the cylinder would vary during five times expansion of two and a half atmosphere steam from $260^{\circ}$ Fahrenheit to $180^{\circ}$ Fahrenheit.*

This jacket steam has also a tendency to produce an increase of pressure by the evaporation of water due to priming, or the admission of water mixed with steam.

Assuming that steam of $2 \frac{1}{2}$ atmospheres pressure is nominally expanded to $\frac{1}{2}$ an atmosphere at the end of the stroke, we should have about 5.93 grains of water at the end of the stroke according to the tables annexed to this paper; but this quantity would afford only 119 grains to each cubic foot of expanded steam-now steam of $\frac{1}{2}$ atmosphere pressure requires 135 grains for its formation; the deficiency of 16 grains is $\frac{\pi}{8}$ th, but as it is probable the deficiency of pressure will be found to be in a similar ratio to the deficiency of water in the expanded steam, capable of affording the full density due to its nominal expansion, the average loss of pressure during 5 times expansion would be about $\frac{1}{20}$ th.

It has been stated to me, on authority on which I place confidence, that extended trials of the steam jacket at Wheal Alfred by Woolf, afforded grounds for the belief that the advantage of the steam jacket amounted to 10 per cent., and Mr. Wicksteed has expressed on a recorded trial a similar opinion. Under these circumstances I conceive I am justified in balancing these corrections, and in using the common theory in expansion calculations, believing that the limits of error will not exert too much influence in the comparison with reported duty.

In mining engines, the boiler at each stroke supplies a quantity of steam to fill the space through which the piston has been moved, until the steam valve is closed, and also a smaller portion to raise the clearance steam compressed by the preceding stroke to an equality with that employed to move the piston. $\dagger$

* The heat expended in the jacket is exclusive of that employed in producing the evaporation. The water condensed in the steam jacket is always in Cornwall returned to the boilers, but at least $\frac{4}{3}$ ths of the heat expended during its conversion into steam has been absorbed; the larger portion of this heat is probably communicated through the cylinder to the steam during expansion when its temperature is so much reduced, and tends to keep up its pressure-but to what extent the most accurate experiments alone can determine.

The jacket steam is considered of value in keeping the top and bottom of the cylinder at an equal temperature, but there seems no direct proof in favour of this opinion.

+ The words compressed steam refer to the appearances shown by indicator diagrams toward the end of the out-door stroke. When the equilibrium valve is freely opened, the unbalanced weight of rods produces out-door velocity, which is checked and brought to rest by the increase of the steam pressure above the piston, acting through a given space by resistance to compression. In case an engine, or rather the pitwork, is out of balance, or the water in fork, and the pumps are not full, either the equilibrium valve connot be opened freely, or it must be closed sooner. 
This clearance steam exerts no power, while the communication between the cylinder and valve is open, but acts during expansion. The complex action is too important to be neglected in expansion calculations, and its effect increases with the amount of expansion. The method I have usually adopted is to measure the portion of the strokes during which the steam valve is open, as the unit of expansion, and to add to the full pressure steam the advantage due to the Hyp Log of the amount of the expansion on the common theory, together with the value of the clearance steam, or to obtain the centre pressure of each volume of expansion, and increase it by the value of the clearance steam.* Perhaps the more correct method would be to calculate the full pressure as before, and then add the clearance steam, before the amount of expansion was calculated; but in this method the expansion shown by the indicator, and the actual expansion in the cylinder do not coincide. When the pressures are all calculated by the centre pressure of each volume of expansion as in the second method, the values of each portion of the steam may be clearly shown at any point of the stroke, and a means is thus obMethods of ascertaining tained of comparing theory with the diagrams formed by
the Steam Pressure in the the Steam Pressure in the
Cylinder. the piston of an indicator. For this purpose, it is obviously a point of extreme importance that the pressure in the cylinder, while the communication with the boiler is open, should be ascertained with as much accuracy as the case admits of.

Woolf employed a mercury gauge, but the results have not been recorded in a satisfactory manner, and the diagrams made by him, with an indicator that I have recently used, have been lost or mislaid.

In $1835 \mathrm{Mr}$. Smith visited Cornwall to inquire, on behalf of Mr. Fairbairn of Manchester, respecting the reported duty of the mining engines, and I am indebted to his kindness for a copy of the diagrams then taken, which coincide with the diagrams subsequently taken by the same instrument in January 1838 , at Davey's and Hocking's engines by Mr. Loam, the engineer of the Consolidated and United Mines, to whom it was subsequently presented.

I propose to advert only to these diagrams, $\uparrow$ in which the coincidence of the

* See Tables at the end of the Paper.

$\uparrow$ It has not been considered necessary to insert the diagrams of these engines. The steam was cut off in Davey's engine, at $\frac{1}{6}$ th of the stroke, and in Hocking's engine at $\frac{1}{7}$ th of the stroke; results which I have since seen confirmed.

The straight line of pressure while the steam valve was open was well defined. 
calculated expansion pressures, and the actual pressures as shown by an indicator are more apparent.

The duty of these engines averaged about 70 millions, the column of water on Davey's shaft is 286 fathoms, and above 200 fathoms at the United Mines, at Hocking's engines, and the load on the piston were respectively $13 \cdot 12 \mathrm{lbs}$, and $12 \cdot 7 \mathrm{lbs}$. per square inch.

The steam valves were rapidly closed, so that the commencement of the expansive action seemed better defined than on the diagrams taken by $\mathrm{Mr}$. Henwood in 1831, in which a convex curve occurs; in those cases I apprehend either the steam valves were more slowly closed, or the clearance spaces were larger, or the full pressure steam was partially wire-drawn during its admission.*

* I do not exactly remember the view I entertained at the period respecting the wire-drawing the steam during its admission from the boiler into the cylinder, the expression refers to the indicator's diagrams taken by Mr. Henwood in 1831 at Huel Towan, the steam valves of which engine was, I understand, $\frac{1}{10}$ th of the cylinder area. A double beat valve of 8 inch diameter on an 80 inch engine I conceive is unable to supply the steam with sufficient rapidity after the piston has attained velocity; the result is a partial expansion before the communication between the boiler and cylinder is closed, and a convex curve of pressures is shown by the indicator.

In the engines at Consols, and at the United Mines, 12 and 13 inch steam valves are used, and the area is about $\frac{1}{4}$ th of the cylinder; and several indicators showed that while the steam valve remained open, steam of the same pressure was admitted into the cylinder, and consequently the expansion curve assumed a concave form, and the actual coincided more closely with the nominal expansion, and with a calculated curve of expansion including the clearance.

However, the duty of several engines with 8 inch valves has exceeded that performed by Davey's, at Consols, and Hocking's engine at the United Mines.

It is possible there may be an advantage in this method from a pressure gained from high steam in the boiler, without any expenditure of water; but whether this plan is preferable to the introduction of equal quantity of water at an equal pressure of steam while the steam valve is open is an undetermined point which involves questions of strength of boilers and cylinders in a manner such as not to admit of an easy solution.

Recently at an engine (Taylor's United Mines) in which a 14 inch steam valve is used for an 85 inch cylinder, several indicators have shown that the steam of the same pressure, while the valve is open, viz., about 25 lbs. above atmosphere, is admitted, and expanded about 12 times; this engine has performed a duty of 100 millions for three months in succession.

The variation of the pressure at the top and bottom of the stroke, in consequence of the proportional greater effect of the clearance steam during expansion, seems to be about as 8 to 1 .

Woolf once attempted to work a 90 inch cylinder with a 4 inch valve; under these circumstances the velocity of the steam through the aperture would approach the limit of its velocity. A duty of 44 millions was the result, but it was subsequently increased to 67 by means of an 8 inch valve. The use of sinall valves may be traced to Woolf's practice. 
Mr. Henwood's most valuable series of indicator diagrams have been published in the Transactions of the Institution, vol. ii., page 49, and are the earliest on record.

It may perhaps be questioned whether the spring of an indicator can follow with sufficient rapidity the decreasing steam pressure during expansion; whether it has not a tendency to exhibit a pressure higher than is exerted by the steam on the surface of the piston, occasioned by the small passage of communication through a wooden plug fitted into a small grease cock, \&c.; still I conceive it may be relied on sufficiently for the steam when the valve is open, at least for those engines in which the full pressure steam exhibits a straight line, from which calculations may be made of the gross power capable of the performance of a duty equal to that reported in $1838 .{ }^{*}$

With a view of showing the progress of improvement, and its connection with the results that may be deduced from theory, it is proposed to select the duty or work performed in the years 1778,1798 , and 1838, as representing

* During the spring $I$ had an indicator constructed with a small piston, under the impression that it might give more accurate results from steam admitted only through the small aperture, a wooden plug was inserted into a small grease cock. I had reason to believe it was properly adjusted for low temperatures, as on a trial at Halen Beagle, on an engine loaded only to $5.76 \mathrm{lbs}$. to the square inch of it, together with the Consol's indicator (made by Woolf), both indicators showed that a decreasing steam pressure crossed the atmospheric line while the steam valve was open. On opening the grease cock at the same moment as the steam valve, a very small puff of steam was visible, and the engine audibly took air before the steam valve closed, some proof of the accuracy of the indicator under these circumstances; but when the smaller indicator was placed on Taylor's engines, where the temperature of the steam was much higher, the first stroke when cold gave a much higher result on the scale than when heated; but the scale when heated coincided with the Manchester indicator, which belonged to Mr. Loam, one of the engineers of the mine. A similar result again occurred after correction by the maker.

I mention this circumstance, as I wish to retract, in some degree, the strong expressions I had used as to the dependence that may be placed on indicators without extreme attention to accuracy of adjustment, as well as to the channel of communication with the cylinder.

I may, perhaps, be permitted to advert to another necessary precaution in their use : several diagrams were recently taken, with this and Woolf's indicator, at Tresavean, with a string from the radius rod, which in this case made rather a greater angle than usual with one of the grease cocks, and also with a parallel motion introduced between the radius rod and indicator, which was fixed by a temporary frame of boards. The average result of the diagrams from the string was an expansion of $5 \frac{1}{2}$, and with the parallel motion of $5 \frac{1}{4}$ times, the difference was about $\frac{1}{10}$ th of a foot in the cylinder, or $1 \cdot 2$ of the point at which the steam valve was closed.

The engine is similar to that at the United Mines, except that the stroke is 12 instead of 11 feet: it had scarcely been at work 3 weeks. The expansion will be soon much increased.

VOL. III.-PART V. 
the performances in Cornwall of Newcomen's atmospheric engine, Watt's low pressure engine, and Watt's engine working high steam expansively.

The duty is a calculated quantity which has at all times been affected by numerous causes, exclusive of the changes that have taken place in the boilers and pitwork, which will be adverted to at the end of this paper.

The annexed list was published in the Appendix to the Ordnance Geological Survey of Cornwall, in reference to water raised from the mines :-

"At all periods, the friction in the pumps on a given load has varied in different shafts from several causes, among which may be enumerated the original quality of the workmanship of the pitwork, the state of order in which it is kept, the length and number of the lifts, the diameter of the pumps, the underlie of the shaft, and the use of flat rods to work a second column of water in another shaft.

"The delivery of the actual water raised, as compared with that calculated has always varied from the impracticability of at all times supplying the exact quantity of water, when pumps of different diameter are employed at different lifts, especially when part of the water is taken from the upper levels, which are liable to be affected by rain in winter, or where the pumps are worked in shafts of unequal depth, independently of leakages of all kinds ; all these circumstances have been neglected for the sake of a convenient method of comparing the work performed by steam engines with different velocities, and loads within certain limits, a course rendered necessary by the nature of the agreement between Messrs. Boulton and Watt and the Mining Adventurers, and, since 1812 , by the spirited competition that had been established among the mining engineers by monthly reports of the duty of the Cornish engines."

It appears to me almost impracticable to attempt, in contracted shafts, to prove the duty in the manner often demanded of weighing the water delivered by each separate lift, without which precaution the real duty could not be exactly ascertained, the adit delivery is unsuited even for an approximation, as it includes the water drained from the upper portions of the lode; the objections above enumerated are less felt in new pitwork, such as is attached to the engines adverted to in these remarks.

The earliest attempt to ascertain the water delivered was water Delivery. made by Mr. Henwood, at Huel Towan, who estimated the deficiency at 7 or 8 per cent; subsequently Mr. Wicksteed weighed and measured the water from three lifts of pumps, at Holmbush, and found the deficiency 10 
per cent. In September, 1839, the water of four strokes of Eldon's engine was separated and measured out of a cistern, the plunger was 14 inches in diameter, the stroke $7 \frac{1}{2}$ feet, and the lift 34 fathoms ; the calculated contents of the pump was 49 gallons, the delivery 47 , a deficiency of 4 per cent.

The position of this pump near a road, over which I constantly passed, enabled me to watch the performances, and in course of 30 visits or more, I never but once detected an air bubble, and even then the amount was scarcely appreciable-less than a cubic inch.

It will perhaps be found a convenient form to exhibit a short

Summary of

summary of the principal changes that have taken place during 60 years, in connection with the amount of duty performed at the periods selected :-

Newcomen's engine, 1778.

1798. Watt's low pressure engine.
Dome boilers under the cylinder.

Separate pump rods for each lift.

Bucket pumps.

Full load for atmospheric pressure, probably 7 or $8 \mathrm{lbs}$. per square inch.

Column of water seldom exceeding 90 fathoms.

Trial at Poldice of two engines 7,126,822 Winchester. in one shaft . . . . . 7,483,163 Imperial.

Average of other engines under 5,000,000 Winchester.

Evaporation of water . . 6 or 7 cubic feet.

Waggon boilers.

Cylinder placed on a separate foundation.

A connected main rod, with pump rods attached to each lift.

Bucket pumps.

Loads generally too heavy for much expansion with low pressure steam.

Duty of 4 best engines $\left\{\begin{array}{l}27,473,500 \text { Winchester. } \\ 28,847,170 \text { Imperial. }\end{array}\right.$

Average of 23 ditto.$\left\{\begin{array}{l}16,925,000 \text { Winchester. } \\ 17,770,000 \text { Imperial. }\end{array}\right.$

Column of water seldom exceeding 160 fathoms.

Evaporation of water from 9 to 10 cubic feet. 
1838. Watt's engine, using high steam expansively.

Trevithick's boilers.

Main rods as before.

Plunger pumps, except at the bottom of the shafts.

Loads from 5 to $18 \mathrm{lbs}$. per square inch.

Expansive action from 2 to 6 times the volume used at full pressure.

Column of water in one instance 286 fathoms.

Evaporation of water from 10 to 14 cubic feet.

Before adverting to the theoretical estimates due to the assumed water evaporation of the different periods, I would observe that the Cornish system of mining accounts, in which no reference is made to the capital expended, has afforded the mining engineers more liberty in the adoption of whatever proportions appeared advantageous in the boiler surface in the flues, or in the size of the cylinder for expansion, and in an increase of strength of the pitwork, required for the first impact of high steam, on commencing motion at each stroke with a pressure that so much exceeds the total resistance, while the resistance exceeds the power in a greater ratio at the end of the stroke.

On the commencement of the present system of encouragement of an improvement of duty, the weakness of the waggon boiler was soon found by Messrs. Jeffree and Gribble, at Dolcoath, to be the limit of expansion and to an increase of duty, much beyond that which had been performed by Watt; but on the adoption of Woolf's cast-iron tubular boilers and a modification of Trevithick's locomotive boilers the strength of the pitwork became the limit to expansion, ${ }^{*}$ and recently in some cases the low rate of duty has been traced to weak pitwork.

* The increasing depth of the shafts, and the greater strain occasioned by high steam at the commencement of motion at each stroke, required a greater strength of main rods, and consequently timber of larger dimensions, and a greater weight of iron connecting straps, on a given water load; these increased weights enabled expansion to be again extended, as the means of equalizing the variable action of the steam became more efficient. This mode of meeting the difficulty arising from the variable pressure of steam worked expansively is due rather to the circumstances under which the mines were worked than to design on the part of the engineers. Mr. Davies Gilbert, I believe, was the first person who fully understood the principle on which the success of expansion depended, and foretold the failure of a scheme suggested by a gentleman of Penzance, who attempted to introduce a scheme of the same nature as the patented contrivances of Watt, for the purpose of equalizing the action of steam during expansion. The inconvenience and expense of breakages during the progress of expansion was experienced in all the deeper mines, and in none more so than in the United Mines, which, 
As it is my object only to deduce a probable duty from the conditions under which the steam is assumed to have been worked in the cylinder by means of a co-efficient, it seems unnecessary to enter upon the question of total resistances of mining engines* (as the subject would require more information

which, about 1814, were about 170 or 180 fathoms in depth, and the levels were below those at Consols, which are situated to the north, and the mine consequently was over pressed with water.

I have recently received an account of the expense of these breakages from a gentleman through whose hands the payments passed, and whose opinion was strongly in favour of strong main rods for mining to meet the strain occasioned by deepening shafts and increased expansion. The difference of the strain on the main rods with 12 times expansion in Watt's engines, or in Woolf's, or rather Hornblow's double cylinder engine, and also in the double cylinder engine recently erected by Sims at Carn Brea, ought to become a subject of consideration to the miner. It may, however, be observed that the only friction due to the additional weight, of rods and balance, is that occasioned by the additional friction thrown on the gudgeons of the balance beams; the cost of the repairs of which would be scarcely appreciable, while the practice of not charging the interest on capital expended in mining machinery in Cornwall renders a commercial comparison impracticable with the amount of annual coal savings.

* The evasion of this question in 1839 arose from the author's inability to assign sufficient reasons for his belief that the friction and other resistances of good mining engines, even in the deep shaft, did not exceed $\frac{1}{2}$ the calculated water-load, or rather that the addition of $\frac{1}{2}$ to the calculated water-load, would represent the total resistances. This idea had been derived from the calculations attached to the diagram forwarded to him by Mr. Fairbairn, and without doubt it has influenced the co-efficient of that he employed for engine and pitwork resistances.

This rule, however, gave a friction much too high for Eldon's Engine United Mines, a 30 inch cylinder employed in raising injection water in a one plunger lift of 34 fathoms, conditions equivalent to those under which the Cornish Engine at Old Ford is worked. Lately the author, on the suggestion of Mr. Parkes, attached a mining gauge to the following engines :-

\begin{tabular}{|c|c|c|c|c|c|c|c|c|c|c|}
\hline 1841 & & 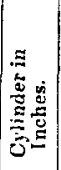 & 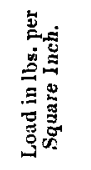 & 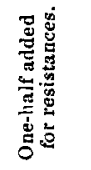 & 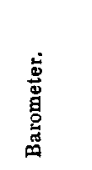 & 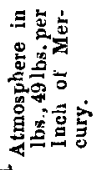 & 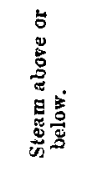 & 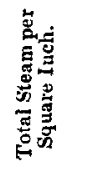 & 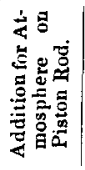 & 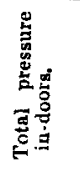 \\
\hline 16 April & North Roskear & 70 & $9 \cdot 54$ & $14 \cdot 31$ & $29 \cdot 4$ & $14 \cdot 4$ & $=0$ & $14 \cdot 4$ & $\cdot 12$ & $14 \cdot 52$ \\
\hline 4 May & - Halen Beagle. & 70 & $5 \cdot 7$ & $8 \cdot 55$ & $29 \cdot 56$ & $14 \cdot 48$ & $-5 \cdot 5$ & $8 \cdot 93$ & $\cdot 12$ & $9 \cdot 05$ \\
\hline 13 Oct. & . Tresavean & 85 & $11 \cdot 91$ & $17 \cdot 91$ & $29 \cdot 5$ & $14 \cdot 45$ & +3 & $17 \cdot 45$ & $\cdot 11$ & $17 \cdot 56$ \\
\hline
\end{tabular}

The steam valve was opened by a hand lever, and the velocity in-doors was extremely slow at North Roskear and Halen Beagle, and the mercury was quite steady; but it amounted to about $\frac{1}{2}$ the usual velocity at Tresavean, and $3 \mathrm{lbs}$. is taken as the mean between the variations of 1 and 4 , as the latter was the pressure for the longer time. The pressure seemed less in the subsequent strokes, when the engine came in-doors slower.

The water load per square inch on the piston in Cornwall is usually calculated from the diameter of the cylinder. 
than I possess, and repeated visits to pitwork under ground), and the duty has been taken $\frac{8}{18}$ ths, leaving $\frac{4}{T^{\circ}}$ ths for friction and other resistances of the calculated power.

It is essential to obtain as near as may be the evaporation of water in cubic feet per bushel of coal, and it is to be regretted that scarcely any attention has been paid to this part of the subject by the engineers of the mines of Cornwall.

The careful experiments of Smeaton cannot be taken as the evaporation due to Cornish practice in 1778, nor can the careless waste of the collieries become our guide. I conceive it probable that it did not exceed 6 cubic feet per bushel in dome boilers.

In this year a trial of two atmospheric engines working in one shaft was made at Poldice (Phil. Trans. 1830), under the superintendence of Messrs. Boulton and Watt, and several gentlemen connected with the mines of the county, when the consumption of coal amounted to 14,080 Winchester bushels in 61 days, and hence each bushel, without allowance for stoppages, worked the engine 6.2385 minutes. The four lifts of pumps were 17 inches in diameter, and raised the water from a depth of 58 fathoms, and made $5 \frac{1}{2}$ strokes of 6 feet in length per minute.

$$
\begin{aligned}
& 17^{2} \times 2 \cdot 0454 \times 58=34,285 \text { load on the shaft. } \\
& \text { ft. stro. min. } \\
& 6 \times 5 \frac{1}{2} \times 6 \cdot 2385=207.87 \text { feet per minute. } \\
& 34,285 \times 207^{\text {lbs. }} \cdot 87=7,126,832 \mathrm{lbs} \text {. raised one foot high. }
\end{aligned}
$$

This amount was subsequently deducted from the duty of Watt's engine, who was entitled by the conditions demanded for the use of his patent to receive ${ }_{3}^{1}$ rd of the value of the remainder, which represented the coal saving effected by his engines. It may be considered a singular circumstance that the neglect and want of attention and skill produced as great a waste of coal in mining engines, after 1800, as the payments made to Watt; and it may be fairly asserted that Watt's counter to ascertain the duty saved nearly the whole amount of the 170,000l. paid to Messrs. Boulton and Watt for coal savings. A portion of this sum arose from the increased duty occasioned by boiler and pitwork improvements, unconnected with the patent.

In 1793 the duty averaged on Watt's authority equalled $19 \frac{1}{2}$ millions.

In August, 1811, the duty of several engines equalled $13 \frac{1}{2}$ millions, being a difference of 6 millions. 
Boulton and Watt's share on $19 \frac{1}{2}$ millions would be-

$$
\begin{aligned}
& \frac{19 \cdot 5-7}{3}=\frac{12 \cdot 5}{3}=4 \cdot 166 \text { duty to be paid as Watt's share, } \\
& \text { and } \frac{4 \cdot 166}{19 \cdot 5}=\cdot 213 \text { of the value of the coal consumed. }
\end{aligned}
$$

The evaporation of Watt's boilers is stated on authority to have been from 8 to 12 cubic feet of water per bushel; but from complaints of the carelessness of enginemen, the frequent stoppages of the pitwork at that period, and waste of steam, and perhaps the practice of allowing the enginemen to take home cinders, would induce me not to rate the evaporation at more than 9 cubic feet per Winchester bushel, expended in the cylinder in mining engines.

The present evaporation of Trevithick's boilers is supposed to be from 10 to 14 cubic feet per imperial bushel (94 lbs.), and even more occasionally, an amount due probably to slow combustion and a large extent of flue surface.* In March, 1826, a trial of $4 \frac{1}{2}$ days' duration at Woolf's engine, a single-acting 90 -inch cylinder at Consols, gave an average result of $11 \cdot 4$ cubic feet per Winchester bushel in boilers with a less flue surface than is at present employed. The water supply was measured by a cistern, the temperature of which was $90^{\circ} \mathrm{F}$, and the temperature of the boiler $263 \cdot 5 \mathrm{~F}$.

$\left.\begin{array}{ccc}\text { Days. } & \text { Hours. } & \text { Cubic Feet. } \\ 1 & 14 & 12 \\ 2 & 24 & 11 \cdot 34 \\ 3 & 24 & 11 \cdot 64 \\ 4 & 24 & 11 \cdot 11 \\ 5 & 24 & 10 \cdot 93\end{array}\right]=11 \cdot 4$.

This engine first reached 67 millions in the report, and 64 millions on a trial, and exceeded the double cylinder engines in duty, but was soon surpassed by the performance of the Huel Towan, constructed by Grose.

* In 1839 I was an advocate of slow combustion and an extended boiler surface. The Cornish evidence in its favour is founded in a great measure on duty, and it has been mixed up with expansion from high steam, and with the additional steam room given, as more flue surface has been added.

Rapid combustion can scarcely be tried in a satisfactory manner with Trevithick's cylindrical mining boiler, unless a steam reservoir is added equivalent to the steam room of the reduced number of boilers.

The water in many mines is extremely bad, and is supposed to be more injurious to the iron when the fires are forced. This revision of opinion has been occasioned by Mr. Wicksteed's experiments, who has thrown some doubt on this subject in relation even to mines. 
The calculated performance of this engine at 5 times expansion-the reported amount-would be-

Temp. $263^{\circ}$ F. . . 3,880,000 lbs. one foot from one cubic foot of water. $\frac{1}{9}$ th $-430,000$ for clearance steam.

$$
\begin{aligned}
& \overline{3,450,000} \\
& \text { ],609 }\{5,551,050
\end{aligned}
$$

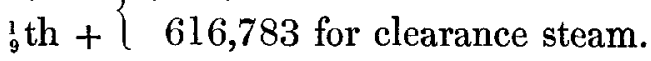

$$
\begin{aligned}
& 9,617,833 \times 11 \cdot 4=108,643,296 \times 6=65,859,777 .
\end{aligned}
$$

A table has been annexed on similar principles of the duty assumed to be due to the different conditions under which the engines were worked in 1778, 1798, and 1838. It is not intended to exhibit any remarkable coincidence where numerous interferences occur, and it is liable to the charge of having been purposely made to coincide, still it affords some grounds for the assertion that the Cornish mining engines ought to perform the reported duties wherever the weight of the main rod is sufficient to absorb the pressure at the commencement, and restore it at the end of the stroke.

In conclusion I propose to advert to some of the changes that have taken place in pitwork during the last 60 years.

Smeaton, in his report on the Chacewater engine, directed a single main rod to be used for the upper lift, and that a cross-head should be attached with rods on each side to work the two lower lifts. The circumstance of a single main rod at the surface was mentioned to me by Mr. M. Moyle, who was an agent in the counting-house of this mine at the period of or soon after its erection. The extension of this plan seems due to Watt or Murdock in lieu of the separate lifts to each pump, with their apparatus of chains at the arc at the end of the beam.

As the economy of coal and greater certainty in the performance of Watt's engine enabled the mines to be worked deeper, the weight of the rod, being in excess, took the engine out of doors too fast without a balance; and either Watt or Murdock (the latter was the party immediately engaged in the suggestion) proposed to substitute a plunger pole for a balance at Huel Maid. In 1796 a plunger pole was employed at Ale and Cakes, a mine which now forms the eastern part of the United Mines.

Under these circumstances no effect of much importance on the duty was produced, but its subsequent introduction as a system of pitwork in lieu of bucket pumps at the bottom of the shaft has eventually caused the slow out- 
door stroke. The facility with which the packing can be kept in order, and the trouble of examining and packing common pumps, contributed to its introduction.

Duty of Stamping

I may perhaps be permitted to refer to an objection which Engines. was long urged against the truth of the reported duty of the pumping engines, I mean the low duty of the stamping engines previous to December, 1835, when 43 millions was reported as the performance of a 32-inch single-acting cylinder engine 10 feet stroke, erected by $\mathrm{Mr}$. James Sims at the Charlestown Mines, near St. Austle. In this engine the crank was applied direct to the cam-shaft. The amount of the duty of this engine, and of two similar engines at Huel Kitty and Carn-Brea constructed by Sims, has been increased to above 60 millions. A donble engine of similar form at Huel Vor by Richards has equalled this performance.

The expansion of these engines varies from $2 \frac{1}{2}$ to 3 times, the steam being cut off at ${ }_{10}^{6}$ or $\frac{I}{3}$ of the stroke; hence the theoretical duty for 12 cubic feet of water evaporated per bushel scarcely reaches 60 millions for 3 times expansion, a coincidence sufficiently close with the reported duty.

It should not be forgotten that the Cornish duty includes the advantage due to a supposed superiority of Welch coal, and to slow combustion in extended flue surface; still a reference to the first principles of steam power may tend to discourage extravagant expectations, and at the same time afford a reasonable hope that a great improvement in duty may be effected in other districts wherever the conditions may be suitable and high steam would not be considered objectionable.

JOHN S. ENYS. 


\begin{tabular}{|c|c|c|c|c|c|c|c|}
\hline \multicolumn{3}{|c|}{ PER SQUARE INCH. } & \multirow[b]{2}{*}{$\begin{array}{l}\text { Temperature } \\
\text { Fahreuleit. }\end{array}$} & \multirow[b]{2}{*}{$\begin{array}{c}\text { Grains of } \\
\text { Waler in One } \\
\text { Cubic Foot. }\end{array}$} & \multirow[b]{2}{*}{$\begin{array}{l}\text { Pressure in Jbs. } \\
\text { per Square Foot. }\end{array}$} & \multirow[b]{2}{*}{$\begin{array}{l}\text { Volume from } \\
\text { one of Water. }\end{array}$} & \multirow[b]{2}{*}{$\begin{array}{c}\text { Efficiency or Gross } \\
\text { Power. }\end{array}$} \\
\hline $\begin{array}{c}\text { Steam in } \\
\text { Atmosphere. }\end{array}$ & $\begin{array}{l}\text { Steam in } \\
\text { Inehes of } \\
\text { Mercury. }\end{array}$ & $\mid \begin{array}{c}\text { Steam in lbs } \\
\text { weight. }\end{array}$ & & & & & \\
\hline $\begin{array}{l}\cdot 125 \\
\cdot 25 \\
\cdot 5 \\
\cdot 75\end{array}$ & $\begin{array}{r}3 \cdot 74 \\
7 \cdot 48 \\
14 \cdot 96 \\
22 \cdot 44\end{array}$ & $\begin{array}{r}1 \cdot 83 \\
3 \cdot 67 \\
7 \cdot 35 \\
11 \cdot 02\end{array}$ & $\begin{array}{l}124 \cdot 6 \\
150 \cdot 8 \\
179 \cdot 6 \\
197 \cdot 6\end{array}$ & $\begin{array}{l}37 \cdot \\
70 \cdot 3 \\
135 \cdot \\
191 \cdot 8\end{array}$ & $\begin{array}{r}264 \cdot 6 \\
529 \cdot 2 \\
1058 \cdot 4 \\
1587 \cdot 6\end{array}$ & $\begin{array}{c}11801^{\cdot} \\
6198 \cdot 38 \\
3229 \cdot 36 \\
2217 \cdot 2\end{array}$ & $\begin{array}{l}3,112,544 \\
3,280,182 \\
3,427,954 \\
3,520,466\end{array}$ \\
\hline $\begin{array}{l}1 \cdot \\
1 \cdot 25 \\
1 \cdot 5 \\
1 \cdot 75\end{array}$ & $\begin{array}{l}29 \cdot 92 \\
37 \cdot 5 \\
44 \cdot 48 \\
52 \cdot 36\end{array}$ & $\begin{array}{l}14 \cdot 7 \\
18 \cdot 37 \\
22 \cdot 05 \\
25 \cdot 72\end{array}$ & $\begin{array}{l}212 \cdot \\
223 \cdot 88 \\
234 \cdot 32 \\
241 \cdot 78\end{array}$ & $\begin{array}{l}256^{\circ} 2 \\
315^{\circ} \\
372^{\circ} \\
+28^{\circ} 8\end{array}$ & $\begin{array}{l}2116 \cdot 8 \\
2646 \cdot \\
3175 \cdot 2 \\
3704 \cdot 4\end{array}$ & $\begin{array}{l}1700 \cdot \\
1384 \cdot 36 \\
1171 \cdot 59 \\
1061.66\end{array}$ & $\begin{array}{l}3,598,560 \\
3,664,016 \\
3,720,332 \\
3,766,145\end{array}$ \\
\hline $\begin{array}{l}2 \cdot \\
2 \cdot 25 \\
2 \cdot 5 \\
2 \cdot 75\end{array}$ & $\begin{array}{l}59.84 \\
67 \cdot 32 \\
74 \cdot 8 \\
82 \cdot 28\end{array}$ & $\begin{array}{l}29 \cdot 4 \\
33 \cdot 07 \\
36 \cdot 75 \\
40 \cdot 42\end{array}$ & $\begin{array}{l}250 \cdot 79 \\
257 \cdot 4 \\
263 \cdot 93 \\
269 \cdot 89\end{array}$ & $\begin{array}{l}485^{\circ} \\
539 \cdot 6 \\
593^{\circ} \\
645^{\cdot} \cdot 4\end{array}$ & $\begin{array}{l}4233 \cdot 6 \\
4762 \cdot 8 \\
5292 \cdot \\
5811 \cdot 2\end{array}$ & $\begin{array}{l}899 \cdot 91 \\
808 \cdot \\
733 \cdot 45 \\
672 \cdot 36\end{array}$ & $\begin{array}{l}3,809,848 \\
3,848,424 \\
3,881,417 \\
3,907,618\end{array}$ \\
\hline $\begin{array}{l}3 \cdot \\
3 \cdot 25 \\
3 \cdot 5 \\
3 \cdot 76\end{array}$ & $\begin{array}{r}89 \cdot 76 \\
97 \cdot 18 \\
104 \cdot 72 \\
112 \cdot 2\end{array}$ & $\begin{array}{l}44 \cdot 1 \\
47 \cdot 77 \\
51 \cdot 44 \\
54 \cdot 94\end{array}$ & $\begin{array}{l}275 \cdot \\
278 \cdot 8 \\
284 \cdot 59 \\
288 \cdot 86\end{array}$ & $\begin{array}{l}702 \cdot 8 \\
755 \cdot 6 \\
808 \cdot 7 \\
861 \cdot 4\end{array}$ & $\begin{array}{l}6350 \cdot 4 \\
6879 \cdot 6 \\
7408 \cdot 8 \\
7938 \cdot\end{array}$ & $\begin{array}{l}620 \cdot 74 \\
576 \cdot 83 \\
539 \cdot 1 \\
506 \cdot 15\end{array}$ & $\begin{array}{l}3,941,947 \\
3,971,359 \\
3,994,084 \\
4,017,818\end{array}$ \\
\hline $\begin{array}{l}4 \cdot \\
4 \cdot 25 \\
4 \cdot 5 \\
4 \cdot 75\end{array}$ & $\begin{array}{l}119 \cdot 68 \\
127 \cdot 1 \\
134 \cdot 61 \\
142 \cdot 12\end{array}$ & $\begin{array}{l}58 \cdot 8 \\
62 \cdot 47 \\
66 \cdot 15 \\
69 \cdot 82\end{array}$ & $\begin{array}{l}292 \cdot 91 \\
295 \cdot 95 \\
300 \cdot 47 \\
304 \cdot 07\end{array}$ & $\begin{array}{c}920 \cdot 2 \\
966 \cdot \\
1017 \cdot 8 \\
1071 \cdot 3\end{array}$ & $\begin{array}{r}8467 \cdot 2 \\
8996 \cdot 4 \\
9525 \cdot 6 \\
10054 \cdot 8\end{array}$ & $\begin{array}{l}477 \cdot 05 \\
450 \cdot 96 \\
428 \cdot 36 \\
406 \cdot 76\end{array}$ & $\begin{array}{l}4,039,277 \\
4,046,926 \\
4,080,386 \\
4,098,890\end{array}$ \\
\hline $\begin{array}{l}5 \cdot \\
5 \cdot 25 \\
5 \cdot 5 \\
5 \cdot 75\end{array}$ & $\begin{array}{l}149 \cdot 6 \\
157 \cdot 08 \\
164 \cdot 08 \\
172 \cdot 72\end{array}$ & $\begin{array}{l}73 \cdot 5 \\
77 \cdot 17 \\
80 \cdot 85 \\
84 \cdot 52\end{array}$ & $\begin{array}{l}307 \cdot 91 \\
311 \cdot \\
314 \cdot 06 \\
316 \cdot 94\end{array}$ & $\begin{array}{l}1122 \cdot 3 \\
1144 \cdot 1 \\
1221 \cdot 7 \\
1271 \cdot\end{array}$ & $\begin{array}{l}10584^{\circ} \\
11123^{\circ} \cdot 2 \\
11652 \cdot 4 \\
12181 \cdot 6\end{array}$ & $\begin{array}{l}389 \cdot 38 \\
372 \cdot 32 \\
356 \cdot 86 \\
342 \cdot 76\end{array}$ & $\begin{array}{l}4,111,118 \\
4,141,399 \\
4,157,282 \\
4,175,365\end{array}$ \\
\hline $\begin{array}{l}6 \cdot \\
6 \cdot 25 \\
6 \cdot 5 \\
6 \cdot 75\end{array}$ & $\begin{array}{l}179 \cdot 62 \\
187 \cdot 1 \\
194 \cdot 58 \\
201 \cdot 74\end{array}$ & $\begin{array}{l}88 \cdot 2 \\
91 \cdot 87 \\
95 \cdot 55 \\
98 \cdot 22\end{array}$ & $\begin{array}{l}320^{\cdot} \\
322 \cdot 77 \\
325 \cdot 86 \\
328 \cdot 71\end{array}$ & $\begin{array}{l}1322^{\circ} 5 \\
1373^{\circ} \\
1422^{\circ} \\
1473^{\circ}\end{array}$ & $\begin{array}{l}12700 \cdot 8 \\
13200^{\circ} \\
13739 \cdot 2 \\
14288 \cdot 4\end{array}$ & $\begin{array}{l}329 \cdot 65 \\
317 \cdot 58 \\
306 \cdot 62 \\
296 \cdot 35\end{array}$ & $\begin{array}{l}4,186,518 \\
4,217,462 \\
4,218,937 \\
4,233,367\end{array}$ \\
\hline $\begin{array}{l}7 \cdot \\
7 \cdot 25 \\
7 \cdot 5 \\
7 \cdot 75\end{array}$ & $\begin{array}{l}209 \cdot 44 \\
216 \cdot 92 \\
224 \cdot 4 \\
231 \cdot 36\end{array}$ & $\begin{array}{l}102 \cdot 9 \\
166 \cdot 57 \\
110 \cdot 25 \\
113 \cdot 92\end{array}$ & $\begin{array}{l}331 \cdot 56 \\
334 \cdot 19 \\
336 \cdot 93 \\
339 \cdot 38\end{array}$ & $\begin{array}{l}1502^{\circ} \\
1570^{\circ} \\
1617^{\circ} \\
1666^{\circ}\end{array}$ & $\begin{array}{l}14817 \cdot 6 \\
15346 \cdot 8 \\
15876^{\circ} \\
16405^{\cdot} 2\end{array}$ & $\begin{array}{l}286 \cdot 7 \\
277 \cdot 77 \\
269 \cdot 52 \\
261 \cdot 66\end{array}$ & $\begin{array}{l}4,243,206 \\
4,261,806 \\
4,278,899 \\
4,292,689\end{array}$ \\
\hline $\begin{array}{l}8 \cdot \\
8 \cdot 25 \\
8 \cdot 5 \\
8 \cdot 75\end{array}$ & $\begin{array}{l}239 \cdot 36 \\
246 \cdot 86 \\
254 \cdot 42 \\
261 \cdot 48\end{array}$ & $\begin{array}{l}117 \cdot 6 \\
121 \cdot 27 \\
124 \cdot 95 \\
128 \cdot 65\end{array}$ & $\begin{array}{l}341 \cdot 83 \\
344 \cdot 22 \\
346 \cdot 6 \\
348 \cdot 99\end{array}$ & $\begin{array}{l}1714^{\circ} \\
1762^{\circ} \\
1811^{\circ} \\
1858^{\circ}\end{array}$ & $\begin{array}{l}16934 \cdot 4 \\
17463 \cdot 6 \\
17992 \cdot 8 \\
1852 \cdot \cdot\end{array}$ & $\begin{array}{l}254 \cdot 27 \\
247 \cdot 31 \\
240 \cdot 76 \\
23457\end{array}$ & $\begin{array}{l}4,305,909 \\
4,318,923 \\
4,331,946 \\
4,350,465\end{array}$ \\
\hline $\begin{array}{l}9 \cdot \\
9 \cdot 25 \\
9 \cdot 5 \\
9 \cdot 75\end{array}$ & $\begin{array}{l}269 \cdot 2 \\
276 \cdot 76 \\
284 \cdot 16 \\
291 \cdot 32\end{array}$ & $\begin{array}{l}132 \cdot 3 \\
135 \cdot 97 \\
139 \cdot 65 \\
143 \cdot 22\end{array}$ & $\begin{array}{l}351 \cdot 32 \\
353 \cdot 62 \\
355 \cdot 8 \\
357 \cdot 71\end{array}$ & $\begin{array}{l}1905^{\circ} \\
1953^{\circ} \\
2001^{\circ} \\
2048^{\circ}\end{array}$ & $\begin{array}{l}19051 \cdot 2 \\
19643 \cdot 4 \\
20109 \cdot 6 \\
20638 \cdot 8\end{array}$ & $\begin{array}{l}228 \cdot 72 \\
223 \cdot 17 \\
217 \cdot 89 \\
212 \cdot 82\end{array}$ & $\begin{array}{l}4,357,390 \\
4,385,817 \\
4,381,680 \\
4,392,547\end{array}$ \\
\hline $10^{\circ}$ & $299 \cdot 2$ & 147 & $359 \cdot 6$ & $2096^{\circ}$ & $21168^{\circ}$ & $207 \cdot 98$ & $4,402,520$ \\
\hline
\end{tabular}

These Tables were calculated from those of Clement Desumes, about three years ago.

The efficiency column is original, in its present form, except for steam of 1 atmosphere strength. See Tredguld, on Steam Engines. 
Extract from the Second Paper, by Davies Gilbert, E:q., relating to Cornish engines in the Phil. Trans. 1830.-Winchester bushel of Coal.

\begin{tabular}{|c|c|c|c|c|c|}
\hline & & & $\begin{array}{l}\text { Diameter of } \\
\text { Cylinder in } \\
\text { Iuches. }\end{array}$ & Duty, 1798. & Observations. \\
\hline & $\begin{array}{l}1 \\
2\end{array}$ & • & $\begin{array}{l}20 \\
21\end{array}$ & $\begin{array}{l}10,015,000 \\
16,385,000\end{array}$ & \\
\hline & $\begin{array}{l}3 \\
4\end{array}$ & - & $\begin{array}{l}45 \\
36\end{array}$ & $\begin{array}{l}29,668,000 \\
28,212,000\end{array}$ & $\left\{\begin{array}{l}\text { It was believed at the time that some inaccuracy must } \\
\text { have occurred in the communications respecting these } \\
\text { two Engines. }\end{array}\right.$ \\
\hline Double & $\begin{array}{l}5 \\
6\end{array}$ & - & $\begin{array}{l}42 \\
63\end{array}$ & $\begin{array}{l}18,193,000 \\
15,190,000\end{array}$ & \\
\hline Double & $\begin{array}{l}7 \\
8 \\
9\end{array}$ & . & $\begin{array}{l}45 \\
45 \\
45\end{array}$ & $\begin{array}{l}15,180,000 \\
15,571,000 \\
15,090,000\end{array}$ & $\begin{array}{l}\text { On the same Mine, the length of strokes in all but one } \\
6 \text { feet }_{1} \text { in that } 8 \text { feet. Average duty of the whole } \\
15,985,000 \text {. }\end{array}$ \\
\hline & 10 & - & 45 & $14,384,000$ & \\
\hline Double & $\begin{array}{l}11 \\
12\end{array}$ & • & $\begin{array}{l}42 \\
42\end{array}$ & $\begin{array}{l}18,740,000 \\
15,532,000\end{array}$ & \\
\hline & 13 & . & 36 & $18,465,000$ & \\
\hline & 14 & - & . & $12,226,000$ & The diameter of the cylinder not returned. \\
\hline & 15 & - & 30 & $14,050,000$ & \\
\hline & 16 & - & 20 & $12,366,000$ & \\
\hline Duuble & 17 & - & $14 \frac{3}{4}$ & $6,097,000$ & \\
\hline & 18 & • & 30 & $13,931,000$ & \\
\hline & 19 & - & 28 & $19,739,000$ & \\
\hline & 20 & • & 36 & $24,514,000$ & \\
\hline & 21 & - & 21 & $13,215,000$ & \\
\hline & $\begin{array}{l}22 \\
23\end{array}$ & • & $\begin{array}{l}20 \\
48\end{array}$ & $15,034,000$ & \\
\hline & 20 & $\cdot$ & 40 & $27,500,000$ & Supposed to be the best Engine. \\
\hline
\end{tabular}

It is to be regretted, that the load in the shaft, and other particulars from which the duty was calculated in 1798, by Mr. Davies Gilbert, have been mislaid, so that I have been unable to give the statements in the same form as the present duty report, neither have they been preserved by $\mathrm{Mr}$. Alfred Jenkins, who was jointly engaged in making the requisite calculations from data supplied by the different mines.

The duty on Watt's authority was higher in 1793: at this period few new engines were erected, and the shafts had been deepened and a deterioration of the engines had occurred by age or bad water, circumstances tending to reduce duty.

North Downs, near Redruth.-Newcomen's Engine, with low Steam.

\begin{tabular}{|c|c|c|c|}
\hline $\begin{array}{l}\text { Water in } \\
\text { Cubic Feet. }\end{array}$ & $\begin{array}{l}3,600,000 \\
\frac{1,800,000}{1,800,000}\left(\frac{1}{2}\right)\end{array}$ & $\begin{array}{l}3,600,000 \\
\frac{1,200,000}{2,}, \frac{(1)}{300,000}\end{array}$ & $\begin{array}{l}\text { lbs. one foot high from the water. } \\
\text { Waste by condensation. } \\
\text { On the piston.-efficiency. }\end{array}$ \\
\hline 6 & $\begin{array}{r}10,800,000 \\
6,480,000\end{array}$ & $\begin{array}{r}14,400,000 \\
8,640,000\end{array}$ & $\begin{array}{l}\text { Efficiency. } \\
\text { Duty. }\end{array}$ \\
\hline $7 \frac{1}{2}$ & $\begin{array}{r}13,500,000 \\
8,100,000\end{array}$ & $\begin{array}{l}18,000,000 \\
10,800,000\end{array}$ & $\begin{array}{l}\text { Efficiency. } \\
\text { Duty. }\end{array}$ \\
\hline 12 & $\begin{array}{l}21,600,000 \\
12,960,000\end{array}$ & $\begin{array}{l}28,800,000 \\
17,280,000\end{array}$ & $\begin{array}{l}\text { Efficiency. } \\
\text { Duty. }\end{array}$ \\
\hline 14 & $\begin{array}{l}25,200,000 \\
15,120,000\end{array}$ & $\begin{array}{l}33,600,000 \\
20,160,000\end{array}$ & $\begin{array}{l}\text { Efficiency. } \\
\text { Duty. }\end{array}$ \\
\hline
\end{tabular}


Watt's Engine, with low Steam.

\begin{tabular}{|c|c|c|c|c|}
\hline 一 & Full Pressure. & Cut off at Four-fifths. & At Two-thiris. & At One-hali. \\
\hline & $3,630,000$ & $\begin{array}{l}3,630,000 \\
\frac{733,260}{4,363,260}\end{array}$ & $\begin{array}{l}3,630,000 \\
\frac{1,470,150}{5,100,150}(405)\end{array}$ & $\begin{array}{l}3,630,000 \\
\frac{2,515,590}{6,145,590}\end{array}$ \\
\hline 8 & $\begin{array}{l}29,040,000 \\
17,424,000\end{array}$ & $\begin{array}{l}34,906,080 \\
20,943,648\end{array}$ & $\begin{array}{l}40,721,200 \\
24,432,720\end{array}$ & $\begin{array}{l}49,164,720 \\
29,494,832\end{array}$ \\
\hline 10 & $\begin{array}{l}36,300,000 \\
21,780,000\end{array}$ & $\begin{array}{l}43,632,600 \\
26,179,560\end{array}$ & $\begin{array}{l}50,901,500 \\
30,540,900\end{array}$ & $\begin{array}{l}61,455,900 \\
36,873,540\end{array}$ \\
\hline 12 & $\begin{array}{l}43,560,000 \\
26,116,000\end{array}$ & $\begin{array}{l}52,359,120 \\
31,415,472\end{array}$ & $\begin{array}{l}61,081,800 \\
36,658,080\end{array}$ & $\begin{array}{l}73,747,590 \\
44,248,248\end{array}$ \\
\hline 14 & $\begin{array}{l}50,400,000 \\
30,240,000\end{array}$ & $\begin{array}{l}61,085,640 \\
36,651,384\end{array}$ & $\begin{array}{l}71,262,100 \\
42,757,260\end{array}$ & $\begin{array}{l}86,636,260 \\
51,981,756\end{array}$ \\
\hline
\end{tabular}

Watt's Engrne, with high Steam.

\begin{tabular}{|c|c|c|c|c|c|}
\hline \multirow[b]{2}{*}{$\underset{\text { pansion. }}{\mathbf{E x}}$} & \multicolumn{3}{|c|}{ Two and a Half A tmospheres. } & \multicolumn{2}{|c|}{ Three Atmospheres. } \\
\hline & 4. & 5. & 6. & 8. & 12. \\
\hline & $\begin{array}{l}3,880,000 \\
\quad 388,000\end{array}$ & $\begin{array}{l}3,880,000 \\
\quad 430,000\left(\frac{1}{6}\right)\end{array}$ & $\begin{array}{l}3,880,000 \\
485,000\left(\frac{1}{8}\right)\end{array}$ & $\begin{array}{l}3,940,000 \\
788,000 \quad(1)\end{array}$ & $\begin{array}{l}3,940,000 \\
985,000\end{array}$ \\
\hline & $\overline{3,492,000}$ & $\overline{3,450,000}$ & $\overline{3,395,000}$ & $\overline{3,1} \overline{52,000}$ & $\overline{2,955,000}$ \\
\hline & $4,839,912(1 \cdot 386)$ & $5,551,050(1 \cdot 609)$ & $6,078,050(\mathrm{I} \cdot 79 \mathrm{I})$ & $6,453,008(2 \cdot 079)$ & $6,340,220(2 \cdot 484)$ \\
\hline & 483,991 & $616,783\left(\frac{1}{9}\right)$ & $759,756\left(\frac{1}{8}\right)$ & $1,291,601 \quad\left(\frac{1}{5}\right)$ & $1,585,055\left(\frac{1}{4}\right)$ \\
\hline & $8,816,903$ & $9,617,833$ & $10,232,806$ & $\overline{10,896,609}$ & $10,880,275$ \\
\hline 10 & $\begin{array}{l}88,169,030 \\
52,801,418\end{array}$ & $\begin{array}{l}96,178,330 \\
55,704,598\end{array}$ & $\begin{array}{r}102,232,060 \\
61,396,836\end{array}$ & $\begin{array}{r}108,966,090 \\
65,379,654\end{array}$ & $\begin{array}{r}108,802,750 \\
65,281,650\end{array}$ \\
\hline 12 & $\begin{array}{r}106,602,836 \\
63,961,701\end{array}$ & $\begin{array}{r}118,213,996 \\
70,928,397\end{array}$ & $\begin{array}{r}122,791,672 \\
73,675,003\end{array}$ & $\begin{array}{r}130,759,300 \\
78,455,4 \leqslant 0\end{array}$ & $\begin{array}{r}130,563,300 \\
78,337,980\end{array}$ \\
\hline 14 & $\begin{array}{r}123,436,642 \\
74,061,985\end{array}$ & $\begin{array}{r}134,649,669 \\
80,789,797\end{array}$ & $\begin{array}{r}143,325,928 \\
85,995,556\end{array}$ & $\begin{array}{r}152,552,315 \\
91,531,389\end{array}$ & $\begin{array}{r}152,323,850 \\
91,397,310\end{array}$ \\
\hline
\end{tabular}

This Table will account for a great variation of duty in mining engines; on visiting several years ago many engines whose reported duty was low, the principal cause was obviously the small extent of expansion used; the reasons assigned were chiefly weak boilers and weak pitwork: in some cases bad pitwork produced a great amount of extra friction and aided in the reduction of the duty, so that the co-efficient would be erroneous, in other cases.

I believe the co-efficient, 4 , will be found to be too high for friction and resistances where the pitwork has been well put up and is nearly new, or during experiments where unlimited quantities of grease are used both in the engine and under ground. 